\title{
Strategic Instruments for University Performance Evaluation in the Context of the Economy Based on Knowledge
}

\author{
Marilena Mironiuc, Ioan-Bogdan Robu, Mihai Carp and Mihaela-Alina Robu
}

"AL. I. CUZA" University of Iaşi, Romania

\begin{abstract}
The first objective of knowledge economy is to capitalize on the human resource through the potential of the knowledge and cognitive skills of the latter. An important role in educating and training the human resource in the economic field is played by specialized universities, which, through master programs and by increasing the performance of the educational act, determine a better insertion of the master degree students in labor market. Starting from the standard form of the Balanced Scorecard, in this paper there has been drawn a strategic instrument for evaluating university performance and the axes and strategic objectives with implications on evaluation and improving educational performance have been founded. After questioning a sample of 147 master degree students, and according to the analysis of the master program accreditation file, the main factors that contribute to increasing university performance have been identified using the regression analysis with dummy variables and the logistic regression analysis. In order to obtain the results of the research, the data has been processed using SPSS 15.0 .
\end{abstract}

Key Words: Knowledge economy, university performance, balanced scorecard, strategic map, dummy variable, logistic regression.

\section{Introduction}

In nowadays society, which is characterized by deep and intense transformations, the economic phenomenon is the nucleus around which all the other components of social life gravitate. Together with the other two fundamental production factors, capital and nature, the human resource determines, in an overwhelming proportion, the development and evolution of economic processes, both from a micro and a macroeconomic perspective. Human capital generates economic benefits mainly due to the quality attribute, developed by acquiring new knowledge and skills, and the amplification of this dimension is a permanent concern reflected in the strategies of any contemporary organization.
Therefore, an extremely important role in educating and training the human resource is played by universities and implicitly by economic faculties, by means of aligning their study programs with the requirements of labor market. In this context, the professional insertion of the students, the acknowledgment and increased visibility of the study programs are the objectives that contribute to improving academic performance. For this, specific evaluation instruments are necessary and applied iteratively, based on a series of specific pertinent indicators, with positive effects on performance at the micro and macroeconomic level in what concerns training the human resource.

\section{Benchmarks of the Knowledge Economy}

The impact of the contributions of this production factor (human resource -

Copyright (C) 2011 Marilena Mironiuc, Ioan-Bogdan Robu, Mihai Carp and Mihaela-Alina Robu. Nasurdin and Quah Chun Hoo. This is an open access article distributed under the Creative Commons Attribution License unported 3.0, which permits unrestricted use, distribution, and reproduction in any medium, provided that original work is properly cited. Contact author: Marilena Mironiuc E-mail: marilena@uaic.ro 
knowledge) on the economic performances that characterize the current period coagulates, form the concept known as the knowledge economy (economy based on knowledge).

The origin of the mentioned concept can be found in the agitation caused by the 80's recession, when traditional industries faced major problems concerning the excess of the production ability and losses in profitability, and governments fought against budget deficits and decreases in real incomes (Harris, 2001). The notion generated by the specific quests of a period of transformations, forced by any difficult situation, marks the beginning of a new economic period, the third industrial revolution, based on the changes generated by the use of computers and of the new information technologies. In this context, world economy has known an ascendant evolution, a trend generated by the use of knowledge and information as determinant factors in increasing productivity and in economic development in general.

The knowledge economy can be defined as the process of product and service creation, based on intense knowledge activities, which contribute, in an accelerated rhythm, to creating a technical-scientific advantage, and which is characterized by fast moral ageing (Carlaw et al., 2006). The main component of "the new economy" is higher trust in intellectual abilities in comparison with the benefits generated by using physical effort or natural resources (Powell, Snellman, 2004). The essential idea of the paradigm of the knowledge economy refers to using a specific set of assets made up of knowledge that must answer the questions "how to?", "who should?" and "what to?", in order to meet the fundamental objective represented by value creation (Cooke and Schwartz, 2008).

\section{University Performance in the Context of Knowledge Economy}

In the current perspective, knowledge economy mainly focuses on the role played by knowledge or by human capital with the purpose of generating economic growth on the long run (Lin, 2007). According to an
OECD report (1996), it is estimated that more than half of the GDP obtained by the component countries of the organization is based on knowledge. However, knowledge economy is far from creating the social equity expected at the world level, because of the differentiated access of the countries to technologies and information: a situation that has a clear impact on the evolution of national economies.

Under these circumstances, the higher education institutions become true partners of economic organizations, and the existential inter-conditioning between them is represented by the knowledge and information they provide to each other. The continuous adaptation of the study programs to the requirements of economic life is a determining condition for preserving this connection that lies at the basis of the entire present socio-economic edifice, defined by the phrase knowledge economy.

The development of knowledge economy places universities in the center of economic revival and social transformation processes, from the perspective of the relations established at the teachinglearning, research and applied solutions level (Perry and Harloe, 2004). In the opinion of Perry and Harloe (2004), the new role attributed to universities in social and economic development leads to a series of internal reforms of the study programs and of the organizational structures of universities, with direct implications on academic performance. The evaluation of academic performance is viewed by Dilts, Haber and Bialik (1994, p. 4) as a system of activities in making decisions, having specific organizational objectives, which reward or sanction individuals and establishing criteria and procedures for collecting the information based on which it is possible to identify whether or not the established objectives have been met.

Useful in making complex decisions concerning the members of the academic community as well as the organization itself, university performance evaluation systems serve to identify and individually 
evaluate any member, allowing the stimulation and training as well as the monitor of the progress of the organization in relation to the established objectives (Reddy, 2011). Most times, academic performance evaluation systems lead to establishing procedures for salary increase, promotion or retention, and are based on a series of evaluation criteria set according to the mission of the university in agreement with the quality standards imposed (Dilts, Haber and Bialik, 1994, pp.5-8). According to Dilts, Haber and Bialik (1994), an extremely important factor of academic performance is teaching regarded as an organized activity that facilitates access to learning and knowledge, having precise cognitive objectives (knowledge, understanding, applications, analysis, synthesis and evaluation) as well as affective objectives (reception and answer, capitalization, organization and characterization).

Of the academic performance evaluation methods, we can mention: formal and informal evaluations made by students, evaluations made by other universities, evaluations of the students' results in exams, evaluations of the chancellorship or of the dean's office, self evaluation, the evaluation of the post-university career of the students, the evaluation made by former graduates and evaluation based on course registration. In the opinion of Barnet et al. (2010), academic performance is also concerned with the quality of the research, and its evaluation is achieved and demonstrated by the publications of the university members (the number of articles with an international impact and of their quotations).

\section{Evaluation and Measurement Instruments of University Performance}

The well-functioning of an organization, as well as its appropriate management, are primarily influenced by the ability of the governance representatives (managers) to make the best decisions and to establish the appropriate strategy and objectives for the development of the organization. According to Niven (2005), the main problems that appear in making decisions are not determined by the lack of answers to certain questions but to their erroneous formulation. In order to meet this challenge, managers can use performance measurement and control systems (Simons, 2000).

In his work, Simons (2000) argues that managers rely on accounting systems (for collecting and processing the information regarding the economic transactions of the organization), on internal control systems (for monitoring the manner in which the operational and strategic organization policies are complied with and achieved) as well as on planning-management systems (that help establishing the strategic policies, the resources necessary for continuing the activity as well as the objectives of the organization). Wegmann (2000) considers that the objectives of a management control system are performance measurement and the strategic management of the organization. Performance is the set of elements that contribute to improving the value-cost pair, so as to meet the strategic objectives (Kaplan, Norton, 2001), and performance evaluation is achieved by stressing indicators that may describe the state of the organization at a specific moment (Wegmann, 2000).

Kaplan and Norton (2001) argue that the only possibility for an organization to have high performance and to create added value is by using appropriate performance measurement instruments. In this sense, Niven (2008) considers that the Balanced Scorcard - BSC is an instrument meant to solve a series of fundamental problems within the organization. Chavan (2009) argues that in order to be successfully implemented, BSC needs dedication and support from the top to the basis of the organization: the attitude of the members of the entity is extremely important in Greiling's opinion (2010).

BSC allows a new management approach in measuring organizational performance, attenuating the limitations of the methods based exclusively on financial indicators (Kaplan and Norton, 2001). In order to transpose the strategy into operational 
objectives and to evaluate it from the perspective of value creation, BSC suggests analyzing four dimensions: financial (characterizing development and profitability at the organizational level and answering the question: What should be done to achieve performance?), clients (quantifies the degree of customer satisfaction, answering the question: What do clients want?), internal processes (regarding the adoption of the best methods and practices in order to satisfy the clients, and providing the answer to: What should be done to meet the clients' needs?) and learning/development (which creates the premises that will lead the organization to change, innovation, and development, based on the competences and motivations of the employees, and answering the question: What will have to be improved for the processes to determine the clients' satisfaction?) (Kaplan and Norton, 2001).

Niven (2008) considers that in order to develop an efficient BSC, this concept has to be promoted and presented at the level of the organization, be accompanied by an education of those who will use it, be associated to an organizational vision, values, and strategies, have the support of managers, allow the development of a strategic map, identify and develop performance measurement indicators, set targets and a hierarchy of managerial initiatives and obtain data for preserving the functionality and for continuous improvement.

The strategic map of a BSC allows viewing the strategy of the organization, describing the processes that should be initiated in order to meet the strategic objectives that lead to customer satisfaction and implicitly to value creation (Kaplan and Norton, 2001). Starting from the current situation of the organization, the strategic map presents the ways to go in order to achieve performance, the causal relations between them and their effects on the objectives of the organization (Niven, 2008). The strategic map is a powerful communication instrument, indicating the vulnerable points of the implemented strategy. BSC includes in its structure: strategic objectives (for the four dimensions: financial, clients, internal processes, learning/development), measure indicators, targets and corrective or perfecting initiatives (Chen, 2006).

In the case of universities, the use of BSC implies improving the activity in order to increase university performance and adding value to the intellectual capital: and meeting the financial objectives is no longer a priority, as it happens in the organizations activating in the business environment (Kong, 2010). For this reason, adapting the standard BSC model represents the differentiation factor between the two approaches, by replacing in its structure the financial axis with the performance axis in which intellectual capital is considered essential.

\section{Research Methodology}

The purpose of this paper is to justify the use of the Balanced Scorecard as an instrument in evaluating and measuring university performance. In our scientific approach, we have resorted to qualitative research (the analysis of the relations between phenomena and the logical justification of the connections between them in order to generate explanations, expressed in statements that can represent the starting point for further research (Smith, 2003)) and quantitative research (that aims to quantify the influences of specific factors on resulting variables). In what concerns the manner of organizing the research, the critical approach, focused on the study of specialized literature in order to provide answers and supporting through arguments the researched problems, has provided a theoretical and logical basis in justifying and supporting the positivist approach. The empiric study concerning the identification of the factors influencing university performance is based on motivating the application of $B S C$ in the case of academic institutions.

\section{The Application of Balanced Scorecard for the Master Program "Accounting, Expertise and Audit"}

The application of BSC as an evaluation instrument for managerial performance in 
the university field presupposes adapting the fundamental structure of the model (the axes) to the specificity of the analyzed area. Therefore, we consider it appropriate to replace the financial axis with the "Performance" axis. The complementary axes are called: "Beneficiaries" - reflecting the opinion of the school population (master degree students); "Internal processes" - expressing the actions that characterize the training of the master degree students; "Learning" - grouping the objectives aimed with the purpose of improving the results obtained at the level of the performed analysis.

The connections established between the objectives set within the Accounting, Expertise and Audit (AEA) master degree are suggestively reflected in the BSC map, whose explanation requires top-down decomposition.

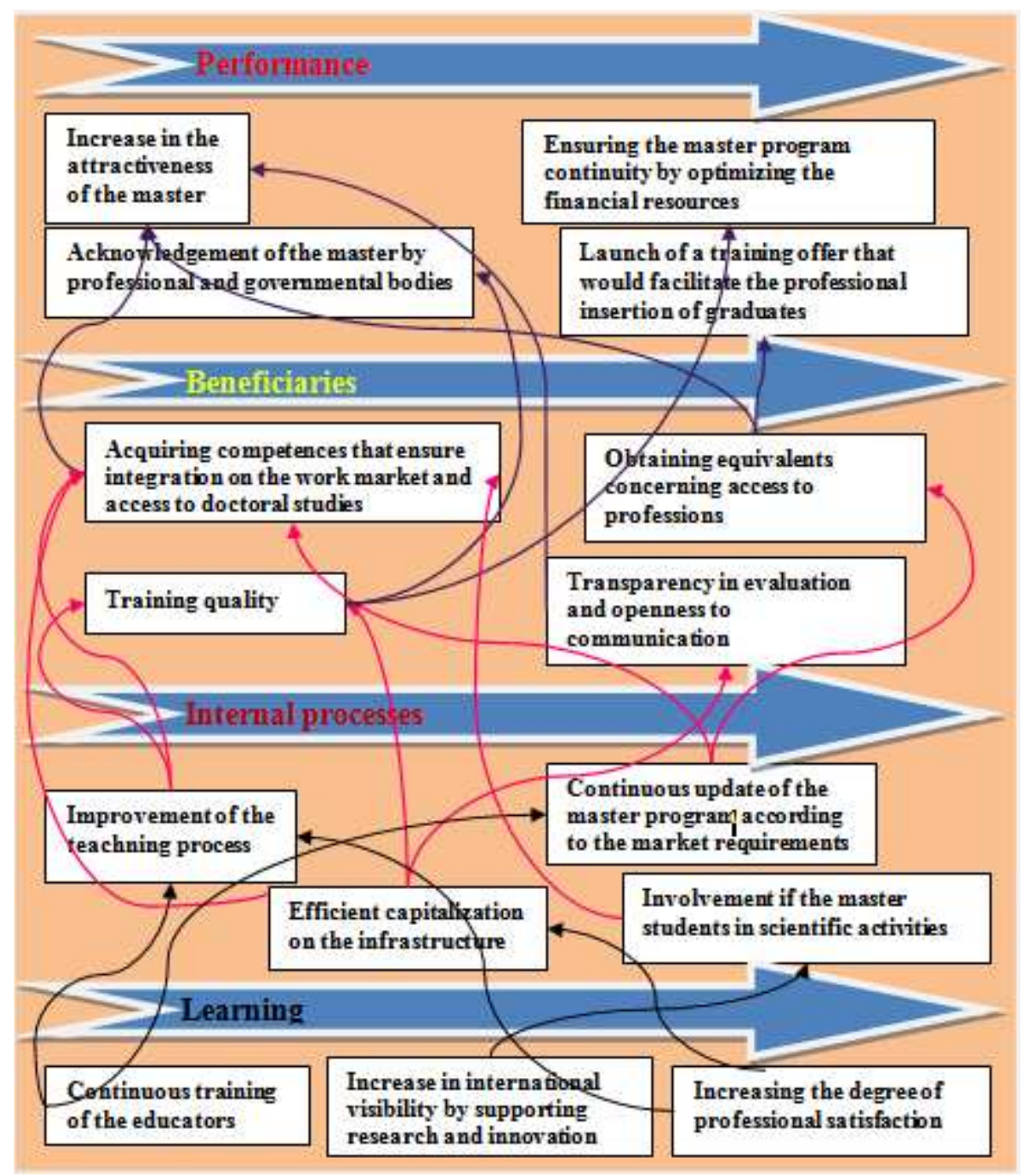

Fig1. The BSC Strategic Map for the AEA Master Program

The fundamental institutional objectives, included in the "Performance" axis, can only be reached by fulfilling those placed on the complementary axes, as the dependence between them is complete.
The performances of the AEA master program reflect the degree of fulfillment of the objectives specific to this axis (Increase in the attractiveness of the master, Ensuring the continuity of the master program by 
optimizing resources, Acknowledgement of the master by professional and governmental bodies, Launching a training offer that would facilitate the professional insertion of the graduates) depends on the degree of fulfillment of the objectives corresponding to the master program beneficiaries and on the organization of the internal and learning processes.

It is necessary to stress the fact that all the objectives included in the managerial strategy are quantified by a series of indicators, which, through an empiric approach, have been assigned a series of target values that reflect an optimal level of efficiency and performance, which should usually be preserved.

\section{Presentation of the General Hypothesis and of the Work Hypotheses}

The current economic context has determined a series of implications at the level of economic higher education because passing on knowledge to students no longer represents the strength of many study programs, as the employers are nowadays interested in the competences of the graduates and in the way they capitalize on the acquired knowledge. In the evaluation of the study program of the Accounting, Expertise and audit (AEA) master of the Faculty of Economy and Business Administration (FEBA) of "Alexandru Ioan CUZA" University of Iaşi (UAIC), we take into consideration the attractiveness of the program for students coming from other specialties, faculties or university centers, the percentage of the master students employed in the accounting financial field before their graduation and the general study average after the first year of study, as indicators that may characterize academic performance.

In order to validate this general hypothesis, the following work hypotheses have been suggested for validation in this article:

$\mathbf{H}_{\mathbf{1}}$ : Using information technologies in classes in order to teach and post supplementary materials necessary to complete the knowledge significantly contributes to increasing the probability for a student from another specialty, faculty or university center (PSAS) to enroll in the master program.

$\mathbf{H}_{2}$ : The probability for a student from another specialty, faculty or university center $(P S A S)$ to enroll in the master program is due to the appreciation of the degree of transparency in communication of the educators and of the people responsible for managing the program.

$\mathbf{H}_{3}$ : The probability for an employed student, enrolled in the master program, to work in the accounting financial field (PSFC) is directly influenced by the academic performance of the student in the first year of the master program: a higher probability implies that the student has accumulated enough knowledge necessary for employment, irrespective of their graduate level specialty.

$\mathbf{H}_{4}$ : The general average grades of a student after the first year of study are significantly influenced by the ratio of the classes using information technologies.

H5: The probability to have a general average of 9 and over 9 out of the maximum 10 is directly influenced by the ratio of the classes using information technologies.

\section{Analyzed Variables}

In order to empirically validate the work hypotheses formulated, a series of qualitative variables has been selected, described through a symbol, an explanation and a computing method:

- PSAS (the probability for a student outside AISM/FEBA to enroll in AEA): natural logarithm (ASSI/(1-ASSI));

- SNCIG (a student who has not graduated AISM/FEBA): 1 for having the characteristic, 0 otherwise; 
- M_FM (satisfied and very satisfied GRST: dummy variable): 1 for having the characteristic, 0 otherwise;

- Neuter (neuter GRST: dummy variable): 1 for having the characteristic, 0 otherwise;

- N_FN (unsatisfied and very unsatisfied GRST): Reference criterion;

- MGS (general average of each student after the first exam session);

- MGS9 (Student with the general average higher than or equal to 9: dummy variable): 1 for having the characteristic, 0 otherwise;

- SM9 (Number of students with an average higher than or equal to 9): count of MGS9 with value 1 ;

- 59 (Number of students with an average smaller than 9): 1-SM9;

- PMM9 (Probability for a student to have an average higher than or equal to 9): natural logarithm (SM9/S9);

- PSAFC (Probability for an employed student to work in the financial accounting field): natural logarithm (NSFC/NSAD);

- DMFC (The employed student works in the financial accounting field: dummy variable): 1 or having the characteristic, 0 otherwise;

- NSFC (Number of students working in the financial accounting field): count of DMFC with value 1 ;

- NSAD (Number of students working in other fields): 1-NSFC.

\section{Data and Sample}

The target population for the performed research is represented by students in the master program Accounting, Expertise and Audit, within the Faculty of Economy and Business Administration of "Alexandru Ioan CUZA" University, Iaşi, in the $1^{\text {st }}$ and $2^{\text {nd }}$ year of study, as well as the first promotion of graduates (2010). The sample extracted as a cluster includes only the students in the second year of the master program and represents a number of 147 subjects. The data has been correlated through a questionnaire, and the master accreditation file and interviewing the master course professors have allowed filling in the BSC from Appendix (table 1, 2, 3, 4). The data has been analyzed using the SPSS 15.0 statistic instrument.

\section{Method}

In order to meet the methodological approach based on validating the general hypothesis by testing the work hypotheses, the regression analysis method has been used: with alternative independent variables (ANOVA and ANCOVA) and with alternative dependent variables (the logistic regression).

In order to perform analyses at the level of the qualitative variables, it is recommended to build alternative variables, also called dummy variables. Alternative variables only allow two values, one being conventionally used to represent the presence of a characteristic and zero otherwise (Gujarati, 2004). According to practical use, the dummy variables are marked by a $D$, the independent numeric variables by an $X$, the dependent variable by a $Y$, and $\alpha_{i}$ and $\beta_{i}$ are used to mark the parameters associated with the independent alternative variables, respectively the independent numeric. The ANOVA models based on the regression analysis are of the form: $Y=\alpha_{0}+\alpha_{1} D+\varepsilon$, where: $D=1$ for meeting certain conditions, and $D=0$ for not meeting the condition. Therefore, the regression can be presented as a conditioned average of the form: $M(Y / D)=\alpha_{0}$, for $D=0\left(\alpha_{0}=\right.$ average for the reference group) and $M(Y / D)=\alpha_{0}+$ $\alpha_{1}$, for $D=1\left(\alpha_{0}+\alpha_{1}=\right.$ average for the group that meets the condition). The estimation of the parameters $\alpha_{0}, \alpha_{0}+\alpha_{1}$ and $\alpha_{1}$ (marked by $\left.a_{0}, a_{0}+a_{1}, a_{1}\right)$ is achieved based on the relations (Gujarati, 2004): $a_{0}=\square_{1}=$ $\left(1 / n_{1}\right) \sum y_{i}, a_{0}+a_{1}=\square_{2}=\left(1 / n_{2}\right) \sum y_{i}, a_{1}=\square_{2}$ $\square$, and $n_{1}, n_{2}$ represent the volumes of the two classification groups. 
In the case of ANCOVA models, they include, beside one or several dummy variables, one or more numeric independent variables $X_{i}$. These regression models are defined by the relation (Hardy, 1993): $Y=\alpha_{0}+\alpha_{1} D+\beta X+\varepsilon$, where $D=1$ for meeting certain conditions, and $D=0$ for not meeting them, and the conditioned averages for this model have the form: $M(Y / D)=\alpha_{0}+\beta X$, for $D=0$, and $M(Y / D)=\left(\alpha_{0}\right.$ $\left.+\alpha_{1}\right)+\beta X$, for $D=1$. In this case, $\alpha_{0}$ is the average value of $Y$, when the imposed condition is not met, and $X=0 ; \alpha_{0}+\alpha_{1}$ is the average level of $Y$ when the group meets the imposed condition; $\alpha_{1}$ is the difference between the average levels of $Y$ for the two groups; $\beta$ determines the influence of variable $X$ on $Y$. These models can be developed using several dummy variables or several independent numeric variables.

For the regression models with dependent alternative variables, the following linear model type is considered: $Y=\beta_{0}+\beta_{1} X+\varepsilon$, where $Y=0$, the case when a characteristic is not achieved and $Y=1$ for the case when the characteristic is achieved. Moreover, since $Y$ is a Bernoulli variable (Gujarati, 2004), it imposes the values one and zero for the probabilities of occurrence: $p$ for $Y=$ 1 and $q$ for $Y=0$. The most representative model is the Logit model, which starts from the idea that the conditioned average, $M\left(Y_{i} / X_{i}\right)=p_{i}$. Is based on a logistic distribution: $M\left(Y_{i} / X_{i}\right)=p_{i}=1 /\left(1+e^{\wedge}\right.$. $\left.\left(\beta_{0}+\beta_{1} \cdot X_{i}\right)\right)=1 /\left(1+e^{\wedge}-Z_{i}\right)$. After applying the reverse function, there will result: $Z_{i}=$ $\ln \left(p_{i} /\left(1-p_{i}\right)\right)$. Therefore, the logistic model is defined by the relation $\mathrm{L}_{\mathrm{i}}=\ln \left(\mathrm{p}_{\mathrm{i}} /\left(1-\mathrm{p}_{\mathrm{i}}\right)\right)=$ $\beta_{0}+\beta_{1} X_{i}+\varepsilon_{i}$ (Gujarati, 2004).

\section{Research Results and Discussions}

At the level of the analyzed sample, after processing the data in SPSS 15.0, a series of descriptive statistics have been obtained concerning the general average of a student, obtained after the first year of study within the master program (Table 1).

Table 1: Descriptive Statistics Regarding the General Average

\begin{tabular}{|l|l|l|}
\hline \multicolumn{1}{|c|}{ General average of a: } & \multicolumn{1}{|c|}{$\begin{array}{c}\text { Average } \\
\text { value }\end{array}$} & \multicolumn{1}{|c|}{$\begin{array}{c}\text { Standard } \\
\text { deviation }\end{array}$} \\
\hline Student who has not graduated AISM/FEBA/UAIC & 7.79 & 2.21 \\
\hline Student who has graduated AISM/FEBA/UAIC & 7.64 & 1.75 \\
\hline Student with a general average of 9 and over 9 & 9.29 & 0.26 \\
\hline Student without a general average of 9 and over 9 & 7.27 & 2.188 \\
\hline Student who has participated in workshops & 8.31 & 1.10 \\
\hline Student who has not participated in workshops & 7.64 & 2.15 \\
\hline
\end{tabular}

According to the obtained results (Table 1), we can notice that certain factors contribute to university performance, reflected in the general average of a student after the first year of master. It is very important that the general average of a student after the first session of exams, who has not graduated from the Accounting and Information System Management (AISM) program of the faculty organizing the AEA master program, is higher compared to that of a student who has graduated from this specialty, which implies that the master program provides the essential knowledge for acquiring a specialty culture, irrespective of the previous background of the student, and the accessibility of the classes reflects a high degree of performance of the master program. Another relevant element consists in the fact that the students' presence in workshops significantly contributes to obtaining better results, through the practical nature of such participation, compared to the students who have never taken part in such activities.

At the level of the work hypotheses, a series of estimations of the parameters of the regression models and statistical tests used for validation have been obtained after data analysis, which are synthesized in the table below (Table 2). 
Table 2: Validation of the Work Hypotheses

\begin{tabular}{|c|c|c|c|c|c|c|c|c|}
\hline \multirow{3}{*}{$\begin{array}{l}\text { Hypothesi } \\
\text { s }\end{array}$} & \multirow{3}{*}{ Test value } & \multirow{3}{*}{ Sig } & \multirow{3}{*}{$\begin{array}{l}\text { Variabl } \\
\text { e }\end{array}$} & \multicolumn{5}{|c|}{ Model parameters } \\
\hline & & & & \multicolumn{2}{|c|}{ Estimations } & \multicolumn{2}{|l|}{ Test } & \multirow{2}{*}{ Sig } \\
\hline & & & & B & $\operatorname{Exp(B)}$ & Type & Value & \\
\hline $\mathrm{H}_{1}$ & $\chi^{2}=54.58$ & $\begin{array}{l}0.0 \\
0\end{array}$ & DITD & -0.02 & 0.979 & Wald & 40.08 & $\begin{array}{l}0.0 \\
0\end{array}$ \\
\hline \multirow{3}{*}{$\mathrm{H}_{2}$} & \multirow{3}{*}{$\chi^{2}=27.04$} & \multirow{3}{*}{$\begin{array}{l}0.0 \\
0\end{array}$} & constant & -1.42 & - & Wald & 24.32 & $\begin{array}{l}0.0 \\
0\end{array}$ \\
\hline & & & M_FM & 0.12 & 0.27 & Wald & 1.13 & $\begin{array}{l}0.0 \\
0\end{array}$ \\
\hline & & & Neuter & -0.03 & 0.24 & Wald & 0.98 & $\begin{array}{l}0.0 \\
0\end{array}$ \\
\hline $\mathrm{H}_{3}$ & $\chi^{2}=73.79$ & $\begin{array}{l}0.0 \\
0\end{array}$ & MGS & 0.44 & 1.56 & Wald & 22.63 & $\begin{array}{l}0.0 \\
0\end{array}$ \\
\hline $\mathrm{H}_{4}$ & $F=518.96$ & $\begin{array}{l}0.0 \\
0 \\
\end{array}$ & DITD & 0.11 & - & $\mathrm{t}$ & 22.78 & $\begin{array}{l}0.0 \\
0 \\
\end{array}$ \\
\hline $\mathrm{H}_{5}$ & $\chi^{2}=44.97$ & $\begin{array}{l}0.0 \\
0\end{array}$ & DITD & -0.02 & 0.982 & Wald & 35.14 & $\begin{array}{l}0.0 \\
0\end{array}$ \\
\hline
\end{tabular}

Based on the obtained results, the regression model corresponding to the five work hypotheses can be represented as follows:

$$
\begin{aligned}
\mathbf{H}_{1}: & P S A S=\ln (A S S I /(1-A S S I))=-0.02 D I T D \\
& \text { and } \left.A S S I=1 /\left(1+\mathrm{e}^{\wedge} 0.02 D I T D\right)\right) ; \\
\mathbf{H}_{2}: & P S A S=\ln (\text { ASSI } /(1-A S S I))=-1.42+ \\
& 0.12 M+F M-0.03 N e u t r \text { and } A S S I=1 /(1 \\
& \left.+\mathrm{e}^{\wedge}-\left(-1.42+0.12 M_{-} F M-0.03 \text { Neutr }\right)\right) ; \\
\mathbf{H}_{3}: & P S A F C=\ln (N S F C / N S A D)=0.44 M G S \text { and } \\
& \left.N S F C=1 /\left(1+\mathrm{e}^{\wedge}-0.55 M G S\right)\right) ; \\
\mathbf{H}_{4}: & M G S=0.11 D I T D ; \\
\mathbf{H}_{5}: & P M M 9=\ln (S M 9 / S 9)=-0.02 D I T D \text { and } \\
& \left.S M 9=1 /\left(1+\mathrm{e}^{\wedge} 0.02 D I T D\right)\right) .
\end{aligned}
$$

The validation of the five models corresponding to the work hypotheses has been done based on the statistical tests $\chi^{2}$ and F. A level of the significance degree (Sig) under the threshold of 0.05 indicates that the models suggested in the hypotheses are valid.

Taking into account the variables introduced in the analysis for each work hypothesis, estimations of the model parameters have been obtained. These (the coefficients of the variables in the model) are tested using the Wald and $t$ (Student) statistics in order to determine the degree of usefulness and significance of the parameter within the suggested model. Moreover, based on Sig, compared to the threshold of 0.05 , we can state with a confidence of $95 \%$ that the parameters of the models in the five work hypotheses are valid and significant.

For work hypothesis $\mathrm{H}_{1}$, we can state with a confidence of $95 \%$ that using information technologies in classes, for teaching purposes and for posting supplementary materials necessary to complete the knowledge, significantly contributes to increasing the probability for a student from another specialty, faculty or university center (PSAS) to enroll in the master program. Therefore, an increase by $1 \%$ of the ratio of the classes using information resources (such as blackboard, FEBA Portal, course presentations in electronic format) will determine a probability of $49.46 \%$ for a student enrolled in the master program not to be one of those who completed the AISM-FEBA (from $0 \%$, in case no course used information resources in teaching): ASSI/(1-ASSI) = 0,979. Therefore, we consider that the impact of information technologies in the teaching activities will represent a determinant factor of the attractiveness of the $A E A$ master program. 
In what concerns the evaluation of the degree of transparency in the evaluation and communication of the educators and of the persons responsible for managing the master, we can state with a confidence of $95 \%$ that a positive evaluation (very satisfied) from the students concerning transparency will determine a relative increase in the probability for a student from another specialty, faculty or university center to enroll in the master program of $0.27(\exp (0.12))$. Therefore, the probability for a student who has not graduated from AISM-FEBA and who considers that they are satisfied or very satisfied in what concerns transparency in evaluation will increase from 19.47\% $(A S S I /(1-A S S I)=\exp (-1.42))$, in case the students are unsatisfied or very unsatisfied with transparency in evaluation and communication) to $21.42 \%$ (ASSI/(1-ASSI) $=\exp (-1.42+0.12))$ in what concerns their wish to enroll for this master.

The relative variation of the probability for an employed student in the $A E A$ master to obtain a job in the financial accounting field, in relation to the increase by one point of the general average obtained after the first year of study is $1.56(\exp (0.44))$. Moreover, we can state with a confidence of $95 \%$ that the students who have obtained a general average of 10 after the first year of the master present a probability of $81.48 \%$ to get employed in the financial accounting field. Also, in this case we consider that achieving good and very good results by the student leads with a very high probability to obtaining a job according to the training acquired in the master program, irrespective of the previous specialty (in any faculty or university center).

In what concerns the influence of the use of information technologies in classes (the blackboard platform, the portal, internet references, indexed databases), we can state with a confidence of $95 \%$ that a single course where computer resources will be used (the weight represents $6.6 \%$ of the total courses taken until the second year of study, semester 2) will determine an increase of the general average by 0.73 .
By validating the previous hypothesis concerning the significant impact of the use of information technologies in master courses, as well as based on the obtained results (table no. 4), we can draw the conclusion that the probability for a student to get a general average of 9 and over 9 in the conditions when all the courses use information resources (100\%) is $49.5 \%(S M 9 / S 9=\exp (-0.02 \cdot 100 \%)$. This stresses the major contribution of information technologies in the educational act, as well as in training the master degree students in acquiring the knowledge necessary to their insertion on the work market.

\section{Conclusions}

In the Knowledge Society, the role of universities is unanimously accepted as that of producing values and transmitting knowledge based on efficient study programs that would insure the student's insertion on the work market. Therefore, it is necessary to evaluate performance and the degree of fulfillment of the objective of the master degree programs in the economic field (especially the financialaccounting field) based on pertinent criteria, using specific instruments. The use of the Balanced Scorecard in evaluating a master program is based on the identification of the components that significantly contribute to increasing the performance and visibility of the program by attracting students from other specialties, faculties or university centers, providing the necessary knowledge for the student's insertion on the work market and improving academic performance (the general average).

Following the application of a Balanced Scorecard within a master program, the main connections between the various objectives corresponding to each axis have been identified (performance, beneficiaries, internal processes, learning), with the purpose of justifying the empirical analysis of the dependencies stressed by the general hypothesis. By validating the five work hypotheses, we can draw the conclusion that the evaluation of the 
performance of a master program is a complex and dynamic process, but the improvement of university transparency and infrastructure, the use of information technologies and the modernization of the school curriculum are some of the factors that significantly contribute to increasing the academic performance. Obtaining this $B S C$ induces an iterative process of observation, evaluation and decisionmaking with the purpose of continuously improving the master program.

However, applying this method implies taking on the compromises generated by the stressed limitations, both at the methodological level and at the procedural one. BSC mainly focuses on the internal reality of the organization, and the influences of the external factors, of other academic institutions, of the socioeconomic environment which are taken into consideration to a very small extent. One of the limitations of this study is represented by the reduced access to a series of data, as well as by the subjective dimension of some of the data used, caused by their collection techniques (questionnaire, interview).

The benefits of such an instrument derive from the ease with which it can be applied and understood by all the actors involved in the educational process, the simplicity of the construction in relation with the complexity of the analyzed phenomenon and last but not least its continuous adaptability. All these characteristics significantly contribute to designating $B S C$ as a strategic instrument for the evaluation of university performance.

\section{Acknowledgements}

This work was supported by the European Social Fund in Romania, under the responsibility of the Managing Authority for the Sectorial Operational Program for Human Resources Development 20072013 [grant POSDRU/CPP 107/DMI 1.5/S/78342].

\section{References}

Barnett, G. A., Danowski, J. A., Feeley, T. H. \& Stalker, J. (2010). "Measuring Quality in Communication Doctoral Education Using
Network Analysis of Faculty-Hiring Patterns," Journal of Communication, 60, 388-411.

Carlaw, K., Oxley, L., Walker, P., Thorns, D. \& Nuth, M. (2006). "Beyond the Hype: Intellectual Property and the Knowledge Society/ Knowledge Economy," Journal of Economic Surveys, 20 (4), 633-690.

Chavan, M. (2009). "The Balanced Scorecard: a New Challenge," Journal of Management Development , 28(5), 393-406.

Chen, S.-H., Yang, C.-C. \& Shiau, J.-Y. (2006). "The Application of Balanced Scorecard in the Performance Evaluation of Higher Education," the TQM Magazine, 18(2), 190205.

Chi-ang Lin, B. (2007). "A New Vision of the Knowledge Economy," Journal of Economic Surveys, 21(3), 553-584.

Cooke, P. \& Schwartz, D. (2008). "Regional Knowledge Economies: an EU-UK and Israel Perspective," Tijdschrift Voor Economische En Sociale Geografie, 99(2), 178-192.

Greiling, D. (2010). "Balanced Scorecard Implementation in German Non-Profit Organizations," International Journal of Productivity and Performance Management, 59(6), 534-554.

Gujarati, D. (2004). 'Basic Econometrics,' the Mcgraw-Hill Companies, New York.

Hardy, M. A. (1993). Regression With Dummy Variables, SAGE University Papers, London.

Harris, R. G. (2001). “The Knowledge-Based Economy: Intellectual Origins and New Economic Perspectives," International Journal of Management Reviews, 3, 21-40.

Kaplan, R. S. \& Norton, D. P. (2001). The Strategy-Focused Organization: How Balanced Scorcerd Companies Thrive in the New Business Environment, Harward Business School Press, Boston.

Kong, E. (2010). "Analyzing BSC and IC's Usefulness in Nonprofit Organizations," 
Journal of Intellectual Capital , 11(3), 284304.

Niven, P. R. (2008). Balanced Scorecard Step-By-Step for Government and Nonprofit Agencies, 2nd Edition, John Wiley \& Sons, New Jersey.

Organisation for Economic Co-Operation and Development (1996). "The KnowledgeBased Economy," Paris. [Online] Available at:

Http://Www.Oecd.Org/Dataoecd/51/8/19

13021.Pdf > [Accessed On January 23th, 2011].

Perry, B. \& Harloe, M. (2004). 'External Engagements \& Internal Transformations: Universities, Localities and Regional Development,' in: A. Harding, A. Scott, S. Laske, C. Burtscher, Ed. 2007. Bright Satanic Mills: Universities, Regional Development and Knowledge Economy.: Ashgate Publishing Limited, Ch. 2, Hampshire.
Powell, W. W. \& Snellman, K. (2004). “The Knowledge Economy," Annual Review of Sociology, 30, 199-220.

Reddy, P. (2011). "The Evolving Role of Universities in Economic Development: the Case of University-Industry Linkages," in: Göransson, B., Brundenius, C., Ed. 2011. Universities in Transition. the Changing Role and Challenges for Academic Institutions, Springer. Ch. 3, London.

Simons, R. (2000). 'Performance Measurement \& Control Systems for Implementing Strategy,' Prentice Hall, Sri Lanka.

Smith, M. (2003). 'Research Methods in Accounting,' SAGE Publication, London.

Wegmann, G. (2000). Les Tableaux de Bord Stratégiques: Analyse Comparative D'un Modèle Nord-Américain et D'un Modèle Suédois, Gestion 2000, Recherches et Publications en Management A.B.S.L., Paris. 
Appendix

Tabel 1: Axis Performance of the Balanced Scorecard for the AEA Master

\begin{tabular}{|c|c|c|c|}
\hline Objectives & Indicators & Symbol & Target \\
\hline $\begin{array}{l}\text { Launching a professional } \\
\text { training offer to facilitate } \\
\text { the insertion of } \\
\text { graduates }\end{array}$ & $\begin{array}{l}\text { The number of candidates enrolled in the } \\
\text { AEA master, for one place budgeted }\end{array}$ & CILB & 1,79 \\
\hline \multirow{2}{*}{$\begin{array}{l}\text { Increasing the } \\
\text { attractiveness of master }\end{array}$} & $\begin{array}{l}\text { The share of total graduate AISM students } \\
\text { enrolled in AEA master }\end{array}$ & ACSI & $80,2 \%$ \\
\hline & $\begin{array}{l}\text { Share graduate from other specialization } \\
\text { and universities in all master's students } \\
\text { enrolled in AEA master program }\end{array}$ & ASSI & $19,8 \%$ \\
\hline $\begin{array}{l}\text { Master recognition by } \\
\text { professional bodies and } \\
\text { government }\end{array}$ & $\begin{array}{l}\text { Share of agreements with professional } \\
\text { bodies in all possible arrangements }\end{array}$ & AOAP & $40 \%$ \\
\hline \multirow{2}{*}{$\begin{array}{l}\text { Ensuring continuity of } \\
\text { the master program by } \\
\text { optimizing financial } \\
\text { resources }\end{array}$} & $\begin{array}{l}\text { The share of total financial resources } \\
\text { budgeted in total financial resources } \\
\text { related to AEA master program }\end{array}$ & RBTR & $55,60 \%$ \\
\hline & $\begin{array}{l}\text { Share of financial resources received from } \\
\text { tuition fees in the total financial resources } \\
\text { related to AEA master program }\end{array}$ & RTTR & $44,40 \%$ \\
\hline
\end{tabular}

Tabel 2: Axis Master Students of the Balanced Scorecard for the AEA Master

\begin{tabular}{|l|l|c|c|}
\hline \multicolumn{1}{|c|}{ Objectives } & \multicolumn{1}{|c|}{ Indicators } & Symbol & Target \\
\hline $\begin{array}{l}\text { Acquiring competences } \\
\text { that would ensure } \\
\text { integration on the work } \\
\text { market and access to } \\
\text { doctoral studies }\end{array}$ & $\begin{array}{l}\text { Ratio of graduates of the AEA master } \\
\text { employed in the total graduates }\end{array}$ & $\begin{array}{l}\text { Ratio of doctoral students graduates of the } \\
\text { AEA master in the total graduates }\end{array}$ & $6.30 \%$ \\
\hline $\begin{array}{l}\text { Obtaining equivalents } \\
\text { regarding access to } \\
\text { professions }\end{array}$ & $\begin{array}{l}\text { Ratio of CECCAR and CAFR interns in the } \\
\text { total graduates }\end{array}$ & STTA & $53.06 \%$ \\
\hline $\begin{array}{l}\text { Transparency in } \\
\text { evaluation and openness } \\
\text { towards communication }\end{array}$ & $\begin{array}{l}\text { Degree of satisfaction of the master } \\
\text { students }\end{array}$ & GRST & $3.27^{*}$ \\
\hline \multirow{2}{*}{\begin{tabular}{l} 
Training quality \\
\cline { 2 - 4 }
\end{tabular}} & $\begin{array}{l}\text { Reneral average of the master program } \\
\text { students enrolled }\end{array}$ & MGMA & 7.71 \\
\cline { 2 - 4 } & $\begin{array}{l}\text { Ratio of student mobilities in the total } \\
\text { master students enrolled }\end{array}$ & TASI & $59.40 \%$ \\
\hline
\end{tabular}

*1 -very unsatisfied, 2 - unsatisfied, 3 - neutral, 4 - satisfied, 5 - very satisfied 
Tabel 3: Axis Internal processes of the Balanced Scorecard for the AEA Master

\begin{tabular}{|c|c|c|c|}
\hline Objectives & Indicators & Symbol & Target \\
\hline $\begin{array}{l}\text { Continuous update of the } \\
\text { master program } \\
\text { according to the } \\
\text { requirements of the work } \\
\text { market }\end{array}$ & $\begin{array}{l}\text { Ratio of the number of newly introduced } \\
\text { disciplines in the total disciplines taught in } \\
\text { the AEA master }\end{array}$ & DNTD & $5.20 \%$ \\
\hline $\begin{array}{l}\text { Improvement of the } \\
\text { teaching process }\end{array}$ & $\begin{array}{l}\text { Ratio of the classes dedicated to } \\
\text { workshops in the total master program } \\
\text { classes per week }\end{array}$ & OWTO & $6.60 \%$ \\
\hline $\begin{array}{l}\text { Involvement of the } \\
\text { master degree students } \\
\text { in scientific activities }\end{array}$ & $\begin{array}{l}\text { Ratio of the students participating in } \\
\text { Olympics in the total students enrolled } \\
\text { annually }\end{array}$ & SPSI & $5.44 \%$ \\
\hline $\begin{array}{l}\text { Efficient capitalization of } \\
\text { the infrastructure }\end{array}$ & $\begin{array}{l}\text { Ratio of the disciplines using computer } \\
\text { resources in the total disciplines of the } \\
\text { AEA master }\end{array}$ & DITD & $60.82 \%$ \\
\hline
\end{tabular}

Tabel 4: Axis Learning of the Balanced Scorecard for the AEA Master

\begin{tabular}{|l|l|c|c|}
\hline \multicolumn{1}{|c|}{ Objectives } & \multicolumn{1}{|c|}{ Indicators } & Symbol & Target \\
\hline $\begin{array}{l}\text { Continuous training of } \\
\text { the educators }\end{array}$ & $\begin{array}{l}\text { Degree of coverage of the number of } \\
\text { teaching classes from the number of } \\
\text { training classes }\end{array}$ & OFOP & 8.84 \\
\hline $\begin{array}{l}\text { Increase in the } \\
\text { international visibility by } \\
\text { supporting research and } \\
\text { innovation }\end{array}$ & \begin{tabular}{l} 
Number of B/B+ grants and publications \\
/indexed databases/ ISI per educator \\
\hline $\begin{array}{l}\text { Increase in the degree of } \\
\text { professional satisfaction }\end{array}$
\end{tabular} & GPCD & 5.7 \\
\hline
\end{tabular}

${ }^{*} 1$-very unsatisfied, 2 - unsatisfied, 3 - neutral, 4 - satisfied, 5 - very satisfied 